ВИХОВАННЯ ГРОМАДЯНСЬКОЇ ВІДПОВІДАЛЬНОСТІ В МАЙБУТНІХ ОФІЦЕРІВ У ВІЙСЬКОВИХ ЗАКЛАДАХ ВИЩОЇ ОСВІТИ

\title{
TRAINING CIVIL RESPONSIBILITY OF FUTURE OFFICERS AT MILITARY HIGHER EDUCATIONAL INSTITUTIONS
}

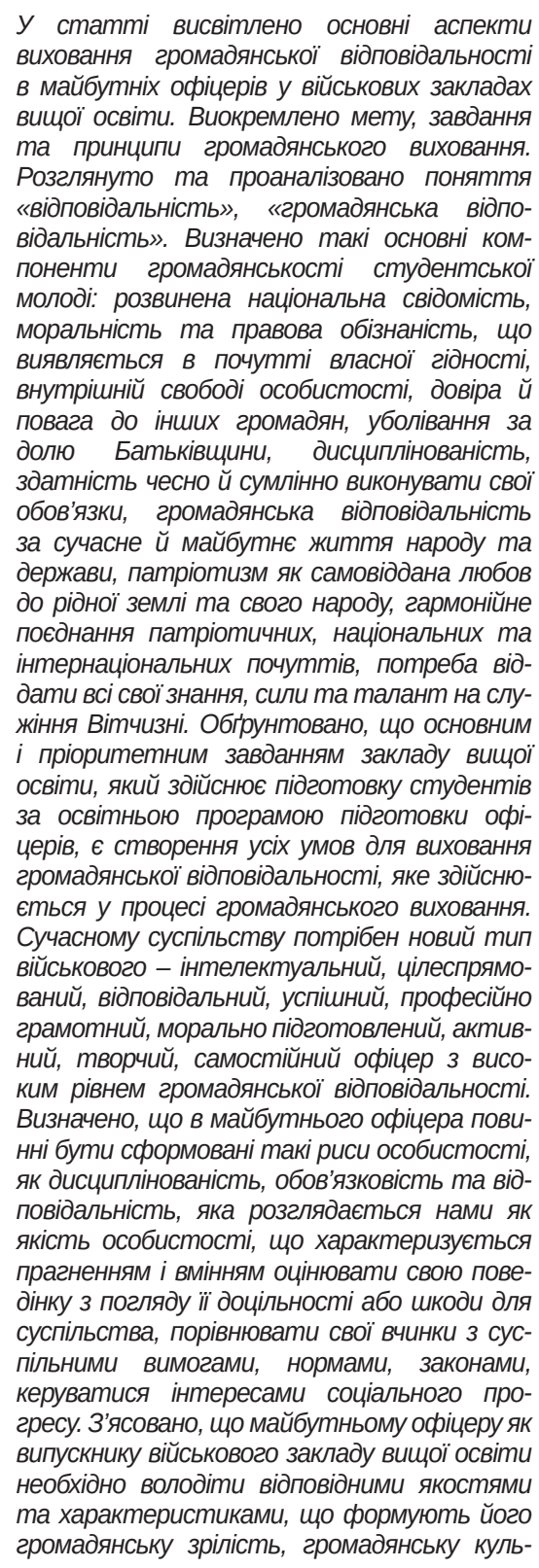

у статті висвітлено основні аспекти вищої освіти. Виокремлено мету, завдання та принципи громадянського виховання. Розглянуто та проаналізовано поняття «відповідальність», «громадянська відпопоненти громадянськості студентської молоді: розвинена національна свідомість, моральність та правова обізнаність, що в почутmі власноі гіठності, повага до інших громадян, уболівання за долю Батьківщини, дисциплінованість, здатність чесно й сумлінно виконувати свої обов'язки, громадянська відповідальність за сучасне и майбутнє життя народу та держави, патріотизм як самовіддана любов ро рідної землі та свого народу, гармонійе інтернаціональних почуттів, потреба віддати всі свої знання, сили та талант на служіння Вітчизні. Обгрунтовано, що основним i піоритетним завданням закладу вищоі за освітньою програмою підготовки офріцерів, є створення усіх умов для виховання громадянської відповідальності, яке здійснюється у процесі громадянського виховання. сучасному суспільству потрібен новий тип ваний, відповідальний, успішний, профресійно грамотний, морально підготовлений, активний, творчий, самостійний офіцер з високим рівнем громадянської відповідальності. Визначено, що в майбутнього офрічера пови нні бути сфрормовані такі риси особистості, пові й якість особистості, що характеризується прагненням і вмінням оцінювати свою поведінку з погляду ії доцільності або шкоди для пільни вимогами, нормами, законами керуватися інтересами соціального прогресу. З'ясовано, що майбутньому офріцеру як випускнику військового закладу вищоі освіти та характеристиками, що фрормують його громадянську зрілість, громадянську куль- туру та громадянську позицію, виховують його громадянську відповідальність.

Ключові слова: громадянська освіта, громадянське виховання, громадянськість, відповідальність, громадянська відповідальнiсmь.

The article deals with the main aspects of training civil responsibility of future officers at military higher educational institutions. The aim, tasks and principles of civil education are singled out. The concepts of "responsibility", "civil responsibility" are considered and analyzed. The basic components of citizenship of student youth are determined: developed national consciousness, morality and legal awareness, manifested in selfesteem, inner freedom of the individual, trust and respect for other citizens, cheering for the fate of the Motherland, discipline, the ability to perform their duties honestly and honestly, civil responsibility for the present and future of the people and the state, patriotism as a selfless love for the native land and its people, harmonious combination of patriotic, national and international feelings, the need to give all their knowledge, strength and talent to serve the Fatherland. It is explained that the main priority of a higher education institution, which trains students for the educational program of officers, is creating all conditions for educating civil responsibility, which is realized in the process of civil education. Modern society needs a new type of military intellectual, purposeful, responsible, successful, professionally literate, morally trained, active, creative, independent officer with a high level of civil responsibility. It is determined that the future officer should be formed such personality traits as discipline, obligation and responsibility, which we consider as a quality personality, characterized by the desire and ability to evaluate their behavior in terms of its expediency or harm to society, to compare their actions with the public requirements, norms, laws, be guided by the interests of social progress. It is determined that future officers as graduates of military higher educational institutions must have the qualities and characteristics that form civil maturity, civil culture and civil status as individuals, raise civil responsibility.

Key words: civil education, civil training, citizenship, responsibility, civil responsibility.
Постановка проблеми у загальному вигляді. Сьогодні проблема виховання майбутніх офріцерів, що мають високий рівень громадянської відповідальності, національної самосвідомості, професіоналізму, творчої активності, постає особливо гостро. Випускники військових закладів вищої освіти (далі 3ВО), які братимуть безпосередню участь у культурному й політичному житті своєї держави, повинні бути патріотами своєї країни. Без патріотизму неможливо уявити майбутнього офріцера.

Одним із найважливіших завдань педагогів $€$ виховання у майбутніх ооріцерів громадянської відповідальності, розуміння належності до українського народу.

Сучасному суспільству потрібен новий тип військового - інтелектуальний, цілеспрямований, відповідальний, успішний, професійно грамотний, морально підготовлений, активний, творчий, самостійний офіцер 3 високим рівнем громадянської відповідальності.

Аналіз останніх досліджень і публікацій. Останнім часом проблема громадянського виховання студентської молоді була предметом різнобічної уваги вчених. Досліджувалися питання 
патріотичного виховання студентів (О. Абрамчук), виховання громадянськості студентів у зарубіжних школах (О. Алєксєєва), громадянського виховання в контексті полікультурного впливу на молодь (Р. Антонюк), становлення культури громадянськості та соціальної відповідальності молоді (Т. Бєлавіна, М. Боришевський), використання мистецтва в системі громадянського виховання молоді (В. Бутенко), інтерпретації творів як засобу громадянського виховання учнів (Л. Бутенко), виховання громадянськості студентів закладів вищої освіти (С. Гнатенко), виховання громадянина на засадах українського народознавства (П. Ігнатенко), громадянського самовизначення (О. Киричук). У науково-педагогічних дослідженнях наголошувалося, що можливості вищої освіти в здійсненні громадянського виховання студентів дозволяють вирішувати широкий спектр питань, пов'язаних із формуванням у студентської молоді громадянської свідомості (почуттів, знань, понять, уявлень, поглядів, переконань, ідеалів, позицій, світогляду), а також громадянської активності (інтересів, орієнтацій, потреб, діяльності, поведінки, організації повсякденного життя, спілкування, праці, навчання, творчості).

Виділення не вирішених раніше частин загальної проблеми. Водночас із забезпеченням своєї суверенності й територіальної цілісності та пошуками шляхів для інтегрування в європейське співтовариство пріоритетним завданням сучасного суспільства є визначення нової стратегії виховання як багатокомпонентної та багатовекторної системи, яка формує майбутній розвиток Української держави. Серед виховних напрямів сьогодні найбільш актуальними $€$ патріотичне й громадянське виховання як стрижневі, основоположні, що відповідають нагальним вимогам і викликам сучасності. Ми вважаємо, що саме виховання громадянської відповідальності має стати стрижневою умовою підвищення якості системи виховної роботи у військових закладах вищої освіти.

Мета статті - висвітлення основних аспектів виховання громадянської відповідальності в майбутніх офріцерів у військових $3 \mathrm{BO}$.

Виклад основного матеріалу. Сьогодні Українська держава та її громадяни стають учасниками кардинальних змін у політиці, економіці та соціальній сорері. Водночас із убезпеченням своєї суверенності й територіальної цілісності та пошуками шляхів для інтегрування в європейське співтовариство пріоритетним завданням суспільного поступу $є$ визначення нової стратегії виховання як багатокомпонентної та багатовекторної системи, яка фрормує майбутній розвиток Української держави [5].

Основним пріоритетним завданням закладу вищої освіти, який здійснює підготовку студентів за освітньою програмою підготовки офріцерів, $€$ створення усіх умов для виховання громадянської відповідальності, яка здійснюється у процесі громадянського виховання. Ефективність громадянського виховання, всебічний розгляд його змісту та структури має важливе значення для майбутніх офріцерів. Вирішення цієї проблеми розширює межі наукового пізнання самого виховного процесу та сприяє виробленню єдиних, конкретних показників, за якими можна $з$ найбільшим ступенем ймовірності судити про оптимальність фрункціонування даної системи.

Виховний процес повинен бути невід'ємною складовою частиною всього освітнього процесу та орієнтуватися на духовні цінності українського народу (національна самосвідомість, ідентичність, самобутність, гідність, соборність, свобода), загальнолюдські цінності, зокрема моральноетичні (гідність, чесність, справедливість, повага до інституту сім'ї, турбота, повага до себе та інших людей) та соціально-політичні (свобода, демократія, культурне різноманіття, повага до рідної мови та культури, патріотизм, шанобливе ставлення до навколишнього природного середовища, повага до закону, відповідальність та солідарність) [5].

У Концепції розвитку громадянської освіти в Україні зазначено, що вагомим елементом громадянської освіти має стати фрормування у громадян відповідального ставлення до захисту суверенітету та територіальної цілісності України, забезпечення безпеки та усвідомлення спільності інтересів людини та держави, формування навичок, необхідних для активної участі у демократичному житті, вільному суспільстві з метою заохочення та захисту демократії та верховенства права, а також розвиток національної ідентичності, що передбачає закріплення фрункціонування державної мови в усіх сорерах суспільного життя водночас із повагою та розвитком мов усіх національних меншин та корінних народів, які проживають на території України [6].

Серед виховних напрямів сьогодення $€$ патріотичне та громадянське виховання як стрижневі, основоположні, що відповідають як нагальним вимогам і викликам сучасності, так і закладають підвалини для формування свідомості нинішніх і прийдешніх поколінь, які розглядатимуть державу як запоруку особистого розвитку, що спирається на ідеї гуманізму, соціального добробуту, демократії, свободи, толерантності, виваженості, відповідальності, здорового способу життя, готовності до змін [8].

Оскільки виховання громадянської відповідальності здійснюється у процесі громадянського виховання, важливо розкрити зміст цього поняття.

У Концепції громадянського виховання особистості в умовах розвитку української державності подано таке визначення громадянського виховання: «Громадянське виховання - це процес фрормування громадянськості як інтегрованої якості особистості, що надає людині можливість 
відчувати себе морально, соціально, політично та юридично дієздатною та захищеною. Воно покликане виховувати особистість чутливою до свого оточення, залучати ії до суспільного життя, в якому права людини є визначальними» [4].

У роботі «Український педагогічний словник» визначено, що громадянське виховання - це фрормування громадянськості як інтегративної якості особистості, яка надає можливість людині відчувати себе юридично, соціально, морально й політично дієздатною. До його основних елементів належить моральна та правова культура, яка виражається в почутті власної гідності, внутрішньої свободи особистості, дисциплінованості, повазі та довірі до інших громадян та до державної влади [3]

У Роботі М.Д. Чумаченка «Педагогічний словник» зазначено, що громадянське виховання - це процес орормування громадянськості як риси особистості, яка характеризується усвідомленням нею своїх прав і обов'язків у ставленні до держави, народу, законів, норм життя, а також турботою про благополуччя своєї країни, збереження людської цивілізації конкретними діями відповідно до власних переконань і цінностей [11].

Громадянськість як риса особистості відображає такі якості:

- патріотичну самосвідомість, громадянську відповідальність, суспільну ініціативність й активність, готовність працювати для розвитку Батьківщини, захищати її, підносити її міжнародний авторитет;

- повагу до Конституції, законів держави, прийнятих у ній правових норм, сорормованість потреби в їх дотриманні, високій правосвідомості;

- досконале знання і володіння державною мовою, турботу про піднесення її престижу;

- увагу до батьків, свого родоводу, традицій та історії рідного народу, усвідомлення своєї належності до нього як його представника, спадкоємця і наступника;

- дисциплінованість, працьовитість, завзятість, почуття дбайливого господаря своєї землі, піклування про її природу, екологію;

- гуманність, шанобливе ставлення до культури, традицій, звичаїв національних меншин, що проживають у країні, високу культуру міжнаціонального спілкування [9].

Е. Панасенко визначила такі компоненти громадянськості студентської молоді: розвинена національна свідомість, моральність та правова обізнаність, що виявляється в почутті власної гідності, внутрішній свободі особистості, довіра й повага до інших громадян, уболівання за долю Батьківщини, дисциплінованість, здатність чесно й сумлінно виконувати свої обов'язки, громадянська відповідальність за сучасне й майбутнє життя народу та держави, патріотизм як самовіддана любов до рідної землі та свого народу, гармонійне поєднання патріотичних, національних та інтернаціональних почуттів, потреба віддати всі свої знання, сили та талант на служіння Вітчизні [7].

Н. Волкова зазначає, що громадянськість - це духовно-моральна цінність, світоглядна та психологічна характеристика особистості, яка визначає її обов'язок і відповідальність перед співвітчизниками, Батьківщиною [2].

Отже, громадянськість як риса особистості відображає такі якості: патріотичну самосвідомість, громадянську відповідальність, суспільну ініціативність й активність, готовність працювати для розвитку Батьківщини, захищати ії, підносити їі міжнародний авторитет; повагу до Конституції, законів держави, прийнятих у ній правових норм, сорормованість потреби в їх дотриманні, високій правосвідомості; досконале знання і володіння державною мовою, турботу про піднесення її престижу; дисциплінованість, працьовитість, завзятість, почуття дбайливого господаря своєї землі, піклування про іï̈ природу, екологію; гуманність, шанобливе ставлення до культури, традицій, звичаїв національних меншин, що проживають у країні, високу культуру міжнаціонального спілкування.

Окрім громадянськості, у процесі громадянського виховання формуються також патріотизм, національна самосвідомість, культура міжетнічних відносин, планетарна свідомість, правосвідомість, громадянська позиція, а також громадянський обов'язок і громадянська відповідальність.

У контексті нашого дослідження проаналізуємо поняття «громадянська відповідальність».

Історико-педагогічний аспект відповідальності особистості пов'язаний із засновниками гуманістичного напряму у вихованні. Так, Я. Коменський у структурі особистості головним вважав почуття совісті та обов'язку. Ж.-Ж. Руссо одним із перших впровадив у науковий обіг поняття «індивідуальний обов'язок особистості». Український фрілософ Г. Сковорода стверджував, що кожна людина відповідальна перед собою та іншими за обране нею місце в системі суспільних відносин і реалізацію своїх можливостей у власній діяльності, людина повинна мати сорормовану звичку відповідальної поведінки.

Цікавим є підхід до розв'язання проблеми виховання відповідальності, запропонований І. Бехом, який пропонує модель виховання, яка ґрунтується на основних принципах особистісно орієнтованого підходу. Її основою є певні інваріанти, дотримання яких допомагає спрямувати педагогічні дії на зняття в дитини внутрішніх бар'єрів і забезпечує розгортання процесу її змістовної, морально перетворювальної діяльності. Переконуючись у доцільності тих внутрішніх зусиль, які необхідні для реалізації такої діяльності, вихованець одержує підстави для її об'єктивної оцінки, усвідомлення значущості для самого себе [1].

У вітчизняній педагогіці поширені дві такі концепції формування відповідальності: 
1) реалізація відповідальної залежності, у межах якої має фрункціонувати вихованець, здійснюючи різні види діяльності. У такому разі методична перевага надається вихованню особистості у колективі і через колектив. Автор цієї концепції А. Макаренко наголошував на вихованні відповідальності як сильного почуття, емоційного переживання особистістю своєї відповідальності;

2) формування відповідальності в особистості у контексті виховання ії громадянськості та морально-духовної ціннісної спрямованості. Ця концепція втілювалась у виховній системі В. Сухомлинського, за словами якого $з$ раннього віку слід формувати здатність жити за принципами добра і відповідно до високих ідеалів, що передбачає розвиток духовності, сердечності, людяності, милосердя тощо [10].

Отже, свідома дисципліна виявляється в усвідомленому виконанні суспільних принципів і норм поведінки, ґрунтується вона на ссрормованості таких рис:

а) дисциплінованість - прагнення й уміння особистості керувати своєю поведінкою відповідно до суспільних норм і правил;

б) обов'язковість - усвідомлення особистістю необхідності дотримання суспільних і моральних норм, підпорядкування своєї поведінки їх вимогам;

в) відповідальність - якість особистості, що характеризується прагненням і вмінням оцінювати свою поведінку з погляду її доцільності або шкоди для суспільства, порівнювати свої вчинки 3 панівними в суспільстві вимогами, нормами, законами, керуватися інтересами соціального прогресу [10].

Ми вважаємо, що виховання громадянської відповідальності повинно базуватися, по-перше, на формуванні громадянських знань, на основі яких фрормуються уявлення про фрорми та способи життя, і реалізації потреб та інтересів особистості в політичному, правовому, економічному, соціальному та культурному просторі демократичної держави загалом та української зокрема; по-друге, на участі в соціально-політичному житті суспільства та практичному застосуванні знань; по-третє, на оволодінні такими громадянськими чеснотами, як норми, установки, цінності та якості, притаманні громадянинові демократичного суспільства.

Висновки. Сучасний етап розвитку українського суспільства передбачає спрямування виховного процесу вищої школи на фрормування громадянськості в студентів, збагачення духовної, національної, мовної культури особистості, широке залучення молоді до громадянських цін- ностей та їх пізнання у процесі профресійної освіти, розвиток у студентів свідомого та відповідального ставлення до питань розбудови українського суспільства, реалізації власного духовного і творчого потенціалу, зміцнення зв'язку між особистими та суспільними інтересами.

Отже, метою громадянської освіти та громадянського виховання має бути формування свідомого громадянина, патріота, просресіонала - людини, якій притаманні особистісні якості й риси характеру, світогляд і спосіб мислення, почуття, вчинки та поведінка, спрямовані на саморозвиток та розвиток демократичного громадянського суспільства як у світі, так і в Україні. Ці вміння повинні органічно поєднуватися з потребою й здатністю діяти компетентно й професійно. Тому майбутньому срахівцю (у контексті нашого дослідження - випускнику військового закладу вищої освіти) необхідно володіти відповідними якостями і характеристиками, що фрормують його громадянську зрілість, громадянську культуру та громадянську позицію, виховують його громадянську відповідальність.

\section{БІБЛІОГРАФІЧНИЙ СПИСОК:}

1. Бех І.Д. Відповідальність особистості як мета виховання. 1994. № 9-10. С. 8-9.

2. Волкова Н.П. Педагогіка : посібник для студентів вищих навчальних закладів. 2002. 576 с.

3. Гончаренко С.У. Український педагогічний словник 1997. 374 с.

4. Концепція громадянського виховання особистості в умовах розвитку української державності: Постанова Президії Акад. пед. наук України від 19 квіт. 2000 р. ; протокол № 1-7/4-49. 2000. № 3. С. 7-13.

5. Концепція національно-патріотичного виховання дітей та молоді, затверджена Міністерством освіти і науки України від 16.06.2015 р. № 641. 2015.

6. Концепція розвитку громадянської освіти в Україні, затверджена Кабінетом Міністрів України від 3 жОВтня 2018 р. № 710-p. 2018.

7. Панасенко Е.А. Ідеал вчителя у вітчизняній педагогічній журналістиці другої половини 19 - початку 20 ст. : дис. ... канд. пед. Наук : 13.00.01. 2001. 230 с.

8. Стратегія національно-патріотичного виховання дітей та молоді на 2017-2020 роки, затверджена Кабінетом Міністрів України розпорядженням від 18 жовтня 2017 р. № 743-р. 2017.

9. Сухомлинська О.В. Громадянськість як феномен виховання. Теор.-метод. пробл. виховання дітей та учнівської молоді. 1999. С. 6-12.

10. Фіцула М.М. Педагогіка : навчальний посібник. Видання 2-ге, виправлене, доповнене. 2006. 560 с. $514 \mathrm{c}$. 